OPEN ACCESS

Edited by:

Boris Rewald,

Universität für Bodenkultur Wien,

Austria

Reviewed by:

Veronica De Micco,

University of Naples Federico II, Italy

José Ignacio Querejeta,

Centro De Edafologia Biologia

Aplicada Del Segura, Consejo

Superior de Investigaciones

Cientificas, Spain

Eleinis Avila-Lovera

University of California, Riverside,

United States

*Correspondence:

Edmundo Acevedo

eacevedo@u.uchile.cl

${ }^{+}$In Memoriam:

This paper is dedicated to the memory of Nicolás Franck.

Specialty section:

This article was submitted to Functional Plant Ecology

a section of the journal

Frontiers in Plant Science

Received: 06 December 2017

Accepted: 22 March 2018

Published: 09 April 2018

Citation:

Garrido M, Silva H, Franck N, Arenas J and Acevedo E (2018) Evaluation of

Morpho-Physiological Traits Adjustment of Prosopis tamarugo Under Long-Term Groundwater Depletion in the Hyper-Arid Atacama Desert. Front. Plant Sci. 9:453. do: 10.3389/fpls.2018.00453

\section{Evaluation of Morpho-Physiological Traits Adjustment of Prosopis tamarugo Under Long-Term Groundwater Depletion in the Hyper-Arid Atacama Desert}

\author{
Marco Garrido ${ }^{1}$, Herman Silva ${ }^{1}$, Nicolás Franck ${ }^{1 \dagger}$, Jorge Arenas $^{2}$ and Edmundo Acevedo ${ }^{1 *}$ \\ 'Soil-Plant-Water Relations Laboratory, Agricultural Production Department, Faculty of Agronomical Sciences, Universidad \\ de Chile, Santiago, Chile, ${ }^{2}$ Faculty of Natural Renewable Resources, Desert Agriculture, Universidad Arturo Prat, Iquique, \\ Chile
}

Water extraction from the underground aquifers of the Pampa del Tamarugal (Atacama Desert, Chile) reduced the growing area of Prosopis tamarugo, a strict phreatic species endemic to northern Chile. The objective of this work was to evaluate the effect of various architectural and morpho-physiological traits adjustment of $P$. tamarugo subjected to three groundwater depletion intervals (GWDr): $<1 \mathrm{~m}$ (control), $1-4 \mathrm{~m}$ and 6-9m. The traits were evaluated at three levels, plant [height, trunk cross-section area, leaf fraction ( $f \mathrm{GCC}$ ), and crown size], organ [length of internodes, leaf mass per unit area (LMA), leaflet mass and area], and tissue level [wood density (WD), leaf ${ }^{13} \mathrm{C},{ }^{18} \mathrm{O}$ isotope composition ( $\delta$ ), and intrinsic water use efficiency (iWUE)]. In addition, soil water content (VWC) to $1.3 \mathrm{~m}$ soil depth, pre-dawn and midday water potential difference $(\Delta \Psi)$, and stomatal conductance $\left(g_{s}\right)$ were evaluated. At the deeper GWDr, P. tamarugo experienced significant growth restriction and reduced $f G C C$, the remaining canopy had a significantly higher LMA associated with smaller leaflets. No differences in internode length and WD were observed. Values for $\delta^{13} \mathrm{C}$ and $\delta^{18} \mathrm{O}$ indicated that as GWDr increased, iWUE increased as a result of partial stomata closure with no significant effect on net assimilation over time. The morpho-physiological changes experienced by $P$. tamarugo allowed it to acclimate and survive in a condition of groundwater depletion, keeping a functional but diminished canopy. These adjustments allowed maintenance of a relatively high $g_{s} ; \Delta \Psi$ was not different among GWDrs despite smaller WWC at greater GWDr. Although current conservation initiatives of this species are promising, forest deterioration is expected continue as groundwater depth increases.

Keywords: leaf isotopic composition, hydraulic lift, phreatophyte, stomatal behavior, water table depth

\section{INTRODUCTION}

Climate change and human intervention have contributed to the reduction of productivity and accelerated death rate of forests in diverse ecosystems (Allen et al., 2010; Williams et al., 2013). This is the case of the Pampa del Tamarugal, a hyper-arid ecosystem in northern Chile, having groundwater as the only significant water source, given the near-absolute absence of rainfall 
(Pliscoff and Leubert, 2006). The Pampa del Tamarugal is a central plateau at about $1,000 \mathrm{~m}$ altitude bordered by the Andes in the east and a Coast range in the west; the groundwater flows from the high Andes and forms a subterranean lake in the central plateau. In this environment grows Prosopis tamarugo, an endemic legume tree, highly adapted to the extreme temperature and radiation of the Pampa del Tamarugal (Lehner et al., 2001; Chávez et al., 2013). P. tamarugo is an evergreen species, which grows throughout the year with a maximum in the springsummer period, and a partial defoliation in winter, when the minimum temperatures are below zero ${ }^{\circ} \mathrm{C}$ (Sudzuki, 1969). $P$. tamarugo has a pivotal root system that access the groundwater as well as system of sub-surface lateral roots that grow in the highly saline upper soil, exerting hydraulic lifting (Aravena and Acevedo, 1985).

The groundwater extraction for urban, agricultural, and mining uses in the Pampa del Tamarugal has generated a negative water balance since 1988 (Rojas et al., 2013). The water depletion of the water table is decreasing the growing area of this species, presently been classified as endangered. The $P$. tamarugo forest decline in the Pintados and Bellavista salt flats (northern area of the Pampa del Tamarugal National Reserve) has been quantified by Chávez et al. (2016), who indicated that, in 2011 out of a total of 73,000 trees, $42 \%$ had less than 0.5 green coverage fraction (range from 0 to1). The study showed that $P$. tamarugo survival is at risk, and it is therefore necessary to enforce conservation measures. In desert ecosystems such as Pampa del Tamarugal, the decline and loss of ecosystem services, such as atmospheric carbon capture and hydrological regulation, are particularly significant given the scarcity of vegetation (Bidak et al., 2015). It follows that understanding the tolerance and acclimation mechanisms that $P$. tamarugo has to cope with water stress would help to predict its chance of survival as well as to design management alternatives to mitigate harmful anthropogenic and climate change effects.

The physiological stress intensity experienced by a tree is determined by a set of morpho-physiological and structural features associated with water absorption, conduction, and loss (Cruiziat et al., 2002; Addington et al., 2006). Facing a water stress, initially the plants are reported to reduce its stomatal conductance with gas exchange consequences (Eamus et al., 2013), what has been studied under natural conditions using stable carbon isotopes in organic matter (Zolfaghar et al., 2017). In the medium-to-long term, the trees make anatomicalstructural modifications leading at maintaining either their water transport efficiency (water transport capacity) and/or safety (increased cavitation resistance) of their hydraulic systems, existing a trade-off between these hydraulic strategies (Tyree et al., 1994; Maherali et al., 2004; Sperry et al., 2008). Addington et al. (2006) found that Pinus palustris in a xeric habitat were shorter in stature, with lower sapwood-to-leaf area ratio, and a higher root-to-leaf area ratio than trees in a mesic habitat. A similar trend was observed in facultative phreatophytes (Banksia attenuata and B. menziesii) growing at a more xeric dune crest site having a xylem more resistant to embolism than trees growing at the wetter bottom slope (Canham et al., 2009).
It is likely that $P$. tamarugo, a species adapted to extreme aridity, would opt to deploy a strategy of hydraulic safety under water stress, investing in producing smaller-diameter xylem vessels (Sperry and Saliendra, 1994; Mainzer et al., 2009) associated with a denser wood, since narrow vessels are immersed in relatively dense wood matrices with more fibers in the xylem tissue (Hacke et al., 2001; Bucci et al., 2004; Fortunel et al., 2014). It should also have a greater investment in root growth (De Micco and Aronne, 2012) and conductive tissue, as well as lower investment in above-ground biomass (Gotsch et al., 2010; Gehring et al., 2016). Leaf area should be reduced via defoliation (Rood et al., 2000; Zolfaghar et al., 2017), and leaf mass per unit area should be increased, thereby increasing wilting resistance (Bucci et al., 2004; Poorter et al., 2009; Shadwell and February, 2017). The deployment of these adjustments should keep a relatively high rate of transpiration per unit leaf area, maintaining gas exchange, however, exposure to lower water potentials could lead to generalized cavitation.

Recent studies show that in conditions of severe groundwater depletion (water table decrease $>6 \mathrm{~m}$ ), $P$. tamarugo decreases its xylem water potentials and maintain a relatively high stomatal conductance measured with porometry, along with a ${ }^{18} \mathrm{O}$ isotopic enrichment in the leaf tissue (Ortiz, 2010) associated with partial stomata closure (Farquhar et al., 2007). In addition, trees experiment a partial defoliation (Ortiz, 2010; Chávez et al., 2013), and a lower investment in radial growth of lateral branches (Decuyper et al., 2016) as well as twig length (Squella, 2013).

The present work was done in a native relict forest of P. tamarugo located in the Salar de Llamara, Atacama Desert, Northern Chile. This formation is a thorny tropical forest, composed mainly of $P$. tamarugo and Caesalpinia aphylla. Groundwater extraction for mining has occurred from the end of 2005 , generating a significant water depletion. Field observations reveal a decline in P. tamarugo health in the area (Garrido et al., 2016), but no deaths have been recorded. Our working hypothesis is that under water stress due to the decrease of the water table, $P$. tamarugo adjusts morphological and structural traits at various levels (canopy, organs, and tissues) leading to maintain gas exchange and hydraulic safety at canopy level. Our objective was to evaluate the effect of the adjustment of various morpho-physiological and structural traits on the water status of P. tamarugo after 10 years of groundwater depletion.

\section{MATERIALS AND METHODS}

\section{Experiment and Environmental Condition}

The study was conducted in the Salar de Llamara (19K $434222 \mathrm{~m}$ E, $7658495 \mathrm{~m} \mathrm{~S}$ ), a tropical hyper-desert bioclimate (Pliscoff and Leubert, 2006) located in the southern extreme of the Pampa del Tamarugal National Reserve, Northern Chile. This place is a native arborescent scrubland of very low plant density, consisting primarily of $P$. tamarugo $(<10 \%$ coverage, with 0.83 trees ha $\left.{ }^{-1}\right)$ and Caesalpinia aphylla $(<25 \%$ coverage). The zone is characterized by high thermal oscillation, low relative humidity, and high incident radiation (Figure 1). For more information about the study site, see Calderón et al. (2015). During 2016, the rainfall was $0.6 \mathrm{~mm}$, and between 2011 and 2015 the accumulated 


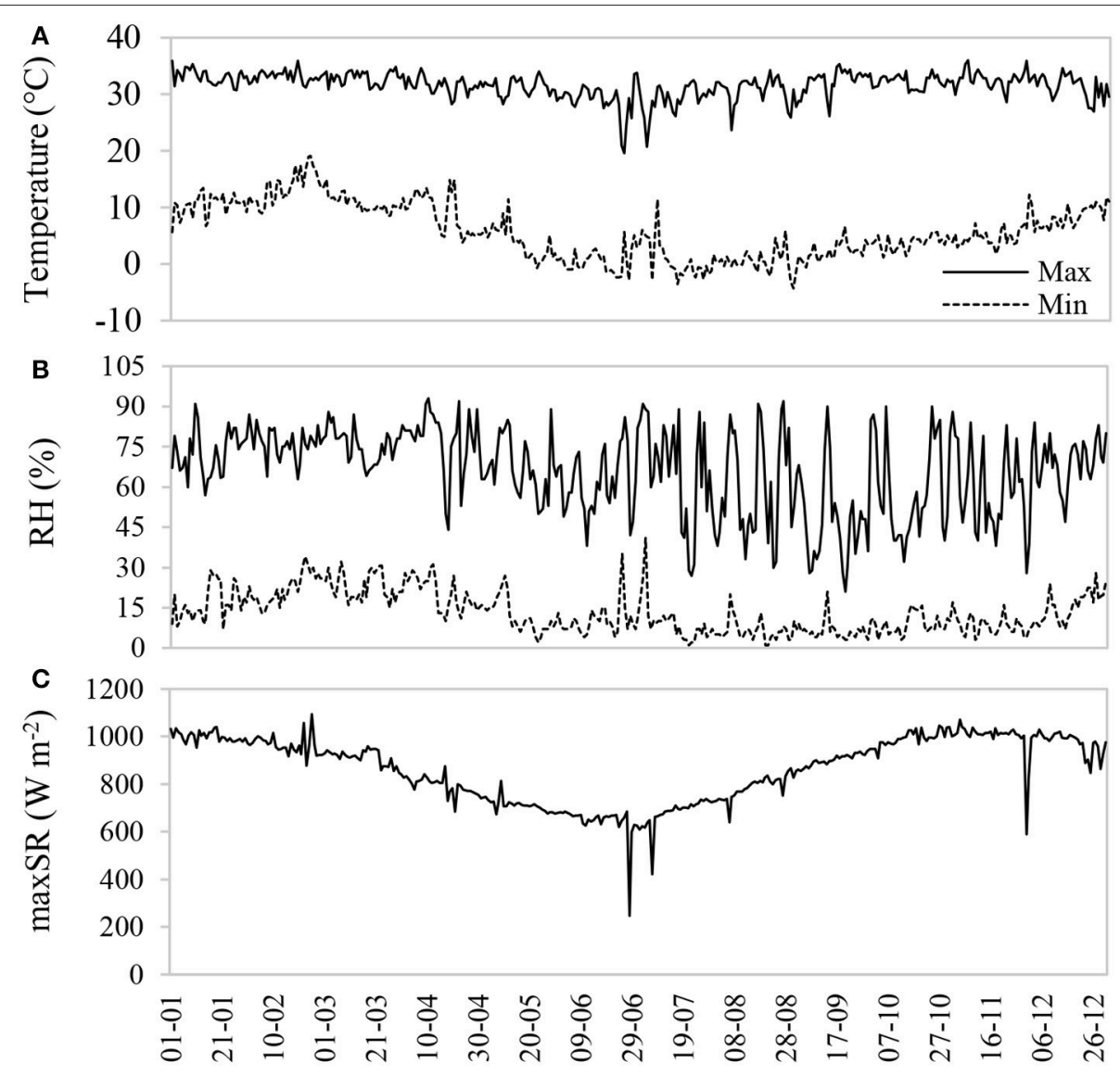

FIGURE 1 | Maximum and minimum air temperature (A), relative humidity (B), and maximum daily solar radiation (C) during 2016 at the Canchones Experimental Station, Pozo al Monte Comuna, Tamarugal Province (19K 444490.5 m E; 7739128.5 m S).

rainfall was $6 \mathrm{~mm}$. The maximum temperature at the sampling dates was $33.1 \pm 1.3^{\circ} \mathrm{C}$ in January, and $30.7 \pm 2.3^{\circ} \mathrm{C}$ in August. The minimum temperature had a greater fluctuation over the year, with monthly averages of $10.4 \pm 1.9^{\circ} \mathrm{C}$ and $0.4 \pm 2.0^{\circ} \mathrm{C}$ for January and August, respectively. A high frequency of below zero temperatures was observed during the winter. The maximum and minimum relative humidity were higher in the summer than in the winter, and the maximum daily incident solar radiation fluctuated between $1000 \pm 21.9$ and $787 \pm 47.1 \mathrm{~W} \mathrm{~m}^{-2}$ between January and August 2016.

Groundwater extraction for mining at the Salar de Llamara started at the end of 2005 (Table 1), causing a groundwater depletion (GWD) gradient around the extraction point (Ortiz, 2010; Garrido et al., 2016). Sixteen P. tamarugo trees were selected along a $4.9 \mathrm{~km}$ north-south linear transect, starting at the water extraction point. Piezometric wells along the transect allowed determining the current and historic phreatic depths (Table 1; www.odea.cl). With this information, three groundwater depletion ranges (GWDrs) were defined: (i) $<1 \mathrm{~m}$ (five trees subjected to a GWDr of less than $1 \mathrm{~m}$ ), (ii) 1-4 m (four trees in a GWDr between 1 and $4 \mathrm{~m}$ ), and (iii) 6-9 $\mathrm{m}$ (seven trees in a GWDr between 6 and $9 \mathrm{~m}$ ). Well PO-01, located $3.2 \mathrm{~km}$ from the extraction site, had a GWD of $1.2 \mathrm{~m}$ in August 2016 (Table 1).
It was assumed that all trees located beyond that well along the transect were subject to a GWDr lower than $1 \mathrm{~m}$.

Measurements were made in January and August 2016, representing the summer (more active vegetative growth period) and winter seasons (lower vegetative growth and partial defoliation), respectively.

\section{Water Content and Soil Chemical Properties}

Soil samples were taken between 0 and $130 \mathrm{~cm}$ depth soil profiles at regular $20 \mathrm{~cm}$ intervals under the canopy of four $P$. tamarugo trees (two trees in GWDr $<1 \mathrm{~m}$, and two in the 6-9 $\mathrm{m}$ GWDr) in January and August. Samples were put in aluminum capsules, weighed to determine wet weight, and dried at $105^{\circ} \mathrm{C}$ to determine the weight of dry soil, and the gravimetric water content was calculated. The bulk density at each depth was measured independently to express the water content on a volumetric basis $\left(\theta ; \mathrm{cm}^{3} \mathrm{~cm}^{-3}\right)$. Approximately $1 \mathrm{Kg}$ soil was sampled in January at 50 and $100 \mathrm{~cm}$ depth. These soil samples were sent to the soil chemistry laboratory of the regional INIA Center (La Platina) for $\mathrm{pH}$, electrical conductivity (EC, $\mathrm{dS} \mathrm{m}^{-1}$ ), organic matter content (OM; \%), total available nitrogen $(\mathrm{N}$; mg 
TABLE 1 | Geographic coordinates and water table depths measured at eight observation wells in the Salar de Llamara, Pampa del Tamarugal, Chile.

\begin{tabular}{|c|c|c|c|c|c|c|c|}
\hline \multirow[t]{2}{*}{ Observation well } & \multirow[t]{2}{*}{ DAP (m) } & \multicolumn{2}{|c|}{$\mathrm{mE}$ and $\mathrm{mS}$ Coordinates } & \multirow[t]{2}{*}{ Altitude (m) } & \multicolumn{3}{|c|}{ Groundwater depth/depletion (m) } \\
\hline & & & & & December 2005* & January 2016 & August 2016 \\
\hline P00 & 0 & 434195 & 7659433 & 754 & 3.3 & $39.3 / 36.0$ & $38.1 / 34.8$ \\
\hline $\mathrm{PO}-7 \mathrm{a}$ & 684 & 434410 & 7658870 & 753 & 4.0 & $15.8 / 11.8$ & $14.7 / 10.7$ \\
\hline PO-6a & 716 & 434400 & 7658748 & 748 & 3.9 & $14.9 / 11.0$ & $15.0 / 11.1$ \\
\hline PO-5 & 886 & 434538 & 7658712 & 751 & 4.2 & $13.0 / 8.8$ & $13.4 / 9.2$ \\
\hline PO-3 & 983 & 434580 & 7658533 & 750 & 4.4 & $11.1 / 6.7$ & $11.6 / 7.2$ \\
\hline PO-4 & 1631 & 434628 & 7657951 & 755 & 5.1 & $10.3 / 5.2$ & $10.6 / 5.5$ \\
\hline PO-8 & 2238 & 434430 & 7657228 & 746 & 4.6 & $7.3 / 2.7$ & $7.5 / 2.9$ \\
\hline PO-1 & 3192 & 434422 & 7656606 & 747 & 5.9 & 7.0/1.1 & 7.1/1.2 \\
\hline
\end{tabular}

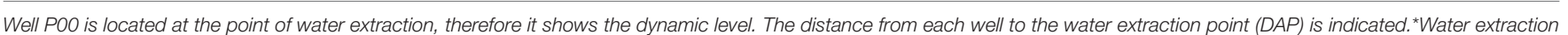
operations started in December 2005.

$\mathrm{Kg}^{-1}$ ), soluble potassium ( $\left.\mathrm{K} ; \mathrm{mg} \mathrm{Kg}^{-1}\right)$, and Olsen phosphorus $\left(\mathrm{P} ; \mathrm{mg} \mathrm{Kg}^{-1}\right)$ analyses.

\section{Tree Water Relations}

Xylem water potential (twig $\Psi$; MPa) and stomatal conductance $\left(\mathrm{g}_{\mathrm{s}} ; \mathrm{mmol} \mathrm{m}^{-2} \mathrm{~s}^{-1}\right)$ were measured during summer and winter at a height of $1.5 \mathrm{~m}$ in the side facing northeast of each tree in the $<1$ and 6-9 m GWDrs ( $n=5$ and $n=7$, respectively). Xylem water potentials were measured at pre-dawn (twig $\Psi_{\mathrm{pd}}$; around 6:00 in summer and around 7:00 in winter; dawn in the area is 06:44 in January and 07:50 in August), and midday (twig $\Psi_{\text {md }}$; between 13:30 and 15:00). The measurements were made following a standard methodology (Scholander et al., 1965) with a pressure chamber (1505D EXP model; PMS Instrument Company). Four twigs per tree were covered with aluminum and plastic bags during the night for twig $\Psi_{\text {pd }}$ measurement, and four other twigs were covered during $2 \mathrm{~h}$ for twig $\Psi_{\text {md }}$ measurement. The $g_{s}$ was measured between 13:30 and 15:00 (at the same time and in the same trees where twig $\Psi_{\text {md }}$ was measured), with an SC-1 Steady State Diffusion Leaf Porometer (Decagon Devices, USA) on 4 leaves per tree, that were fully expanded and exposed to radiation.

\section{Leaf and Wood Traits}

The leaf mass per unit area (LMA; $\mathrm{g} \mathrm{cm}^{-2}$ ) and wood density (WD; $\mathrm{g} \mathrm{cm}^{-3}$ ) were measured in winter 2016, when the growth rate of $P$. tamarugo decreased. Leaf and branch samples were taken from the northeastern side of the trees in $<1$ and 6-9 m GWDrs ( $n=5$ and $n=7$, respectively), stored in bags, placed in coolers with gel packs, and taken to the laboratory for analysis. Leaf area was measured from a composed sample of leaf $(\sim 50 \mathrm{~g}$ of fresh weight per tree) using digital image analysis in ImageJ (Schindelin et al., 2015). The samples were placed in a forced air oven (Venticell, MMM Group) at $60^{\circ} \mathrm{C}$ until they reached a constant weight to determine leaf dry matter. LMA $\left(\mathrm{g} \mathrm{cm}^{-2}\right)$ was estimated as the ratio between the leaf dry mass and the leaf area of each sample. The branches (two per tree) were cut into segments of roughly $10 \mathrm{~cm}$ from the base and cut again in six cylinders of similar diameter for wood density measurement. The bark and spines were removed from each segment. Fresh wood volume was determined using the dimensional method (Pérez et al., 2013), measuring the diameter (average from the diameter at the base, center, and end of the segment) and length of the cylinder. Subsequently, the samples were placed in a $60^{\circ} \mathrm{C}$ oven until constant weight, and WD was estimated as the ratio between the dry mass and fresh volume of each segment.

The color of eight leaves per tree was measured during the January 2016 field campaign. For this, a Munsel ${ }^{\circledR}$ color chart for plant tissue was used in fully expanded leaves exposed to radiation in the northeastern face of the tree, and the frequency of colors in each tree was registered.

\section{Stable Isotope Analysis and Intrinsic Water Use Efficiency (iWUE)}

The observed variation in intrinsic water use efficiency may be due to net assimilation $\left(A_{n}\right)$ variation (with a constant gs) or to $g_{s}$ changes (with constant $A_{n}$ ), Scheidegger et al. (2000) proposed a model of analysis based on the use of the different possible associations between $\delta^{13} \mathrm{C}$ and $\delta^{18} \mathrm{O}$. The use of $\delta^{18} \mathrm{O}$ is based on its negative association with $g_{s}$, when $g_{s}$ is the limiting factor for transpiration (Farquhar et al., 2007). Two assumptions had to be met for $\mathrm{g}_{\mathrm{s}}$ estimation: the air relative humidity and $\delta^{18} \mathrm{O}$ of the water source should not differ between sites (Farquhar et al., 2007; Roden and Siegwolf, 2012). Our study was conducted in a forest of isolated individuals, and the groups of evaluated trees were less than $4 \mathrm{~km}$ apart across a homogeneous topography, so atmospheric conditions were similar between sites. In addition, the groundwater $\delta^{18} \mathrm{O}$ along the studied transect had an average value of $-6.2 \pm 0.19 \%$ o (unpublished data, personal communication, Geohidrologia Consultores, ARCADIS, Chile), so the assumptions were met.

Although Scheidegger et al. (2000) developed their interpretation model in herbaceous species under natural conditions, it has also been applied to woody species studies such as Quercus frainetto Ten. under natural conditions (Colangelo et al., 2017), as well as in retrospective studies in Fagus sylvatica and Nothofagus spp. (Tognetti et al., 2014), and in Scots pine (Voltas et al., 2013). The efficacy of the model has been evaluated by Roden and Farquhar (2012) measuring $\delta^{13} \mathrm{C}$ and $\delta^{18} \mathrm{O}$ in growth rings of Eucalyptus globulus Labill. and Pinus radiata D. 
under controlled conditions. The authors evaluated the effect of different abiotic stresses, (low irradiance, nitrogen deficit, heat, and drought) on the isotopic composition of wood and cellulose simulating climate change. In their assay the authors hypothesized that it was possible to predict $A_{n}$ and $g_{s}$ behavior from the stable isotopes values. Although the dual isotopic model did not perform best in all the evaluated scenarios, it was particularly efficient under drought and heat stress (under low relative humidity and light restriction only).

In order to determine the leaf isotopic composition of ${ }^{13} \mathrm{C}$ $\left(\delta^{13} \mathrm{C} ; \%\right)$ and ${ }^{18} \mathrm{O}\left(\delta^{18} \mathrm{O} ; \% 0\right)$, a sample of leaves was taken from the trees at the GWDrs $<1$ and $6-9 \mathrm{~m}$ in summer, and from all trees along the transect in winter. Sampling was carried out in branches with northeastern exposure at a height of roughly $1.5 \mathrm{~m}$, selecting fully expanded leaves of good phytosanitary and nutritional status. The size of each sample was $\sim 50 \mathrm{~g}$ of fresh weight per tree. The leaves were dried at $60^{\circ} \mathrm{C}$ in a forced air oven (Venticell, MMM Group) until constant weight, and then crushed in a mill to a homogeneous powder. Two subsamples from each sample were weighed with an analytical balance (Precisa 125A) in tin and silver capsules for $\delta^{13} \mathrm{C}$ and $\delta^{18} \mathrm{O}$ measurements respectively. Each leaf sample isotopic composition was determined using standard procedures at the Stable Isotope Laboratory at the Faculty of Agronomic Sciences (University of Chile), with an INTEGRA2 isotopic ratio mass spectrometer (IRMS) (Sercon Ltd. Cheshire, UK), with a precision of 0.3 and $0.5 \%$ or $\delta^{13} \mathrm{C}$ and $\delta^{18} \mathrm{O}$, respectively. The measurements were standardized to the relative values of Pee Dee Belemnite (PDB) and Vienna Standard Mean Ocean Water (VSMOW) for carbon and oxygen, respectively.

$$
\delta(\% \mathrm{o})=\frac{R_{\text {sample }}}{R_{\text {standard }}}-1
$$

where $\mathrm{R}_{\text {sample }}$ and $\mathrm{R}_{\text {standard }}$ are the isotopic ratios of ${ }^{13} \mathrm{C} /{ }^{12} \mathrm{C}$ or ${ }^{18} \mathrm{O} /{ }^{16} \mathrm{O}$ of the samples and PDB or VSMOW, respectively. Carbon isotope discrimination $\left(\Delta^{13} \mathrm{C}\right.$; \%o ) was estimated as follows (Farquhar et al., 1982):

$$
\Delta^{13} C=\frac{\delta^{13} C_{a i r}-\delta^{13} C_{\text {plant }}}{1+\delta^{13} C_{\text {plant }}}
$$

where $\delta^{13} C_{a i r}$ is the carbon isotope composition of air, with a value of $-8.15 \%$ o (CDIAC, 2008, available at http://cdiac.ess-dive. lbl.gov/trends/co2/iso-sio/iso-sio.html), and $\delta^{13} C_{\text {plant }}(\%$ o) is the carbon isotopic composition of leaf tissue (Equation 2). Given that $\Delta^{13} \mathrm{C}$ is related to the ratio between the concentration of carbon dioxide in the intercellular spaces and the atmosphere $\left(\mathrm{C}_{\mathrm{i}} / \mathrm{C}_{\mathrm{a}}\right)$, and assuming that stomatal conductance to water is 1.6 times the conductance to $\mathrm{CO}_{2}$, the intrinsic water use efficiency (iWUE) can be estimated from $\Delta^{13} \mathrm{C}$ as follows:

$$
i W U E=\left[1-\left(\frac{\Delta^{13} C-a}{b-a}\right)\right] \frac{C_{a}}{1.6}
$$

where $a$ is the fractionation caused by the diffusion of $\mathrm{CO}_{2}$ from the atmosphere to the intercellular spaces of the leaf $(4.4 \%)$, $b$ is the fractionation caused by the isotope discrimination of ${ }^{13} \mathrm{CO}_{2}$ of RuBP carboxylase $\left(27 \%\right.$ ), and $C_{a}\left(\mu \mathrm{mol} \mathrm{mol}{ }^{-1}\right)$ is the atmospheric carbon dioxide concentration which was obtained from NOAA ESRL (https://www.esrl.noaa.gov), being 402.52 and $402.25 \mu \mathrm{mol} \mathrm{mol}^{-1}$ in January and August 2016, respectively.

\section{Tree Biometric Variables}

The green canopy cover fraction ( $f$ GCC) of trees at the GWDrs $<1$ and 6-9 $\mathrm{m}$ was estimated using digital image analysis based on objects using eCognition ${ }^{\circledR}$ Developer. The variable was defined as the green surface of a side of a $P$. tamarugo tree in the total area of the same side and was determined according to the methodology described by Chávez et al. (2013) and Garrido et al. (2016). The relationship between $f$ GCC and the total crosssectional trunk area of each tree ( $\Sigma \mathrm{CSA}$ ) was calculated as an approximation to the leaf area: sapwood area $\left(\mathrm{A}_{1}: \mathrm{A}_{\mathrm{S}}\right)$.

In order to assess the magnitude of $f$ GCC change within the year, a relative difference of green coverage from January to August (RfGCC) was calculated as follows.

$$
\mathrm{R} f G C C=\frac{f G C C_{j a n}-f G C C_{a u g}}{f G C C_{j a n}}
$$

where $f \mathrm{GCC}_{j a n}$ and $f \mathrm{GCC}_{\text {aug }}$ are the highest and lowest $f \mathrm{GCC}$ respectively.

The number of trunks per tree and their perimeters were measured at one-meter height with a tape to estimate the cross-sectional area of each trunk $\left(\mathrm{CSA}, \mathrm{m}^{2}\right)$. Strong allometric relationships between sapwood area and cross-sectional area have been reported under various conditions (Eamus et al., 2000; Kelley et al., 2007; Zolfaghar et al., 2017). Thus, CSA can be used as an approximation for the sectional area of water conduction tissue. The height of the tree $(\mathrm{m})$ was measured with a Tandem360R/PC altimeter (Suunto, Finland), and the crown size $\left(\mathrm{m}^{2}\right)$ was estimated as the average circular area between the largest and smallest diameter of each tree. The average internode length (IntLength; $\mathrm{cm}$ ) was measured in 20 terminal branches per tree at $\sim 1.5 \mathrm{~m}$ height in the north-east face and calculated as the ratio between the length of the branch and the number of internodes.

\section{Statistical Analysis}

All statistical analyses were done using the InfoStat interface (Di Rienzo et al., 2011) with $\mathrm{R}$ version 3.2.1 (R Core Team, 2015). Mixed general linear models with a structure of repeated measurements over time were used, where GWDr, season (winter and summer), and the interaction between GWDr and season were fixed factors. The autocorrelation structure of the repeated measurements on the same individual in summer and winter was modeled using a compound symmetry function (Pinheiro and Bates, 2000). With variables measured only in winter, GWDr was defined as a fixed factor and the tree as a random factor, and a heteroscedastic model was used. Model selection was based on the fulfillment of the statistical analysis assumptions and by using AIC index values (Akaike information criterion; Bozdogan, 1987) as the selection criteria. Post-hoc Fischer's LSD analyses were used when appropriate. 


\section{RESULTS}

\section{Environment of the Study Site and $P$. tamarugo Water Status}

The GWDr $\times$ Season interaction was not significant for soil volumetric water content $(\theta ; p=0.808)$, but GWDr was significant independently ( $p<0.001)$. The average soil profile volumetric water content \pm standard error $(n=4)$ was $0.265 \pm 0.031 \mathrm{~cm}^{3} \mathrm{~cm}^{-3}$ in the GWDr $<1 \mathrm{~m}$; roughly 2.5 times higher than that observed in the 6-9 m, which had an average of $0.098 \pm 0.035$. In both GWDrs water content tended to increase with soil depth (Figure 2A). This was consistent with the presence of roots observed in the field, which increased with depth. The volumetric soil water content at each tree and in each sampling season was positively and significantly correlated to the $t w i g \Psi_{p d}$ measured in the same trees (Figure 2B).

The chemical soil analysis (Table 2) from the two test pits in each GWDr indicated that the soil from the $<1 \mathrm{~m}$ tended to have a similar $\mathrm{pH}$, lower $\mathrm{EC}$ and $\mathrm{K}$, and higher $\mathrm{OM}, \mathrm{N}$, and P-Olsen

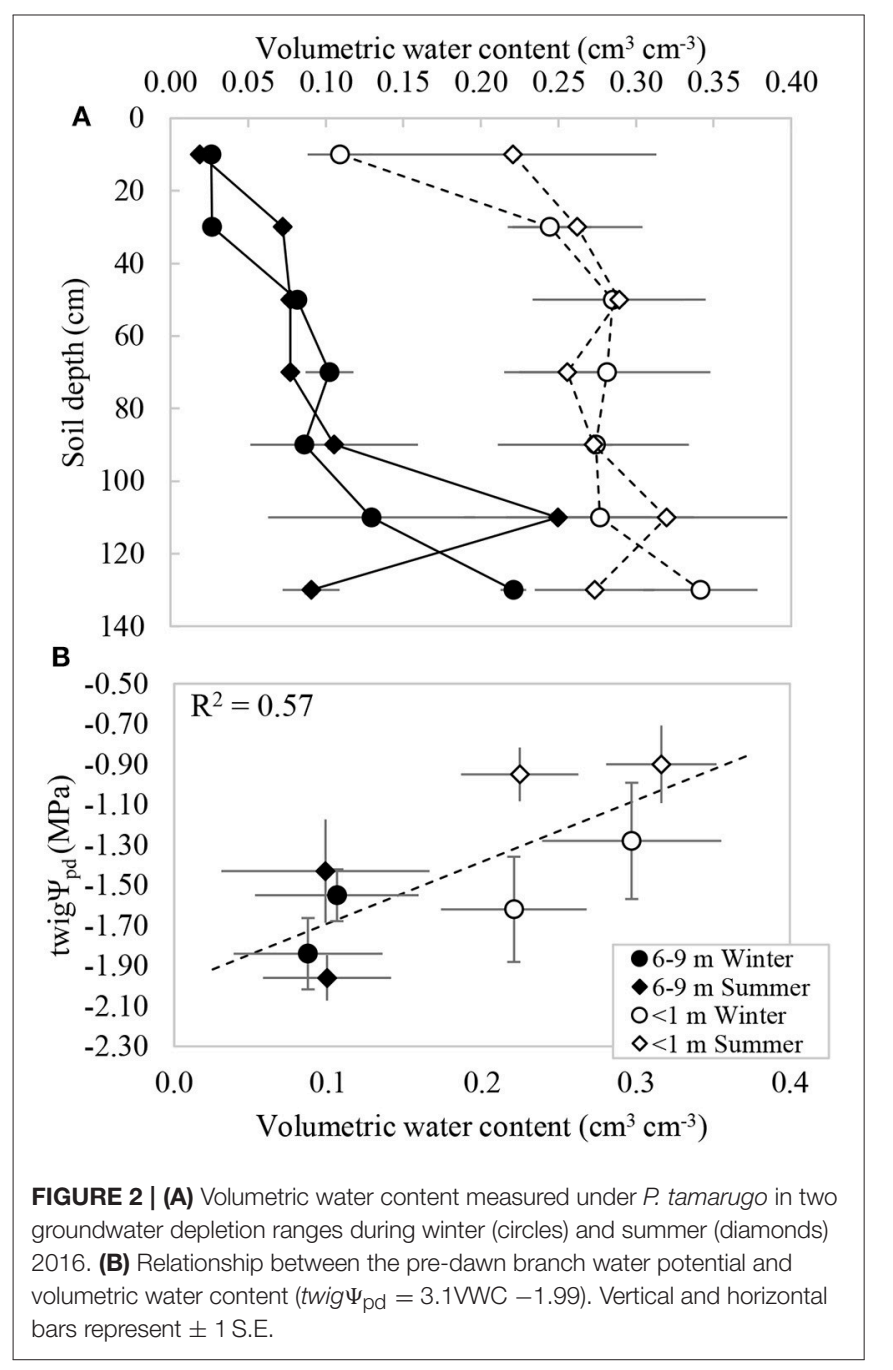

contents (on average between 50 and $100 \mathrm{~cm}$ deep) compared to the 6-9 m GWDr. In the soil profile, OM, N, K, and P-Olsen tended to be higher in the upper $50 \mathrm{~cm}$ than deeper in the soil.

\section{Water Stress Adjustment of Morpho-Physiological and Structural Traits at Canopy Level}

The GWDr $\times$ Season interaction was not significant for $f$ GCC. The $<1 \mathrm{~m}$ GWDr had a significantly higher $f \mathrm{GCC}(p=0.0002)$ than the 6-9 m GWDr, and fGCC was higher in summer than winter $(p=0.0001)$. Winter defoliation estimated through RfGCC was significantly higher $(p=0.0194)$ in the 6-9 m GWDr (Figure 3).

LMA was significantly higher in the 6-9 m GWDr, having a significantly smaller leaflet area compared to the $<1 \mathrm{~m}$ GWDr. The individual leaflet mass was not different between GWDrs. Nor there were significant differences in WD (Table 3). Leaf color had a hue (5GY) and chroma (4) equal in each tree measured,

TABLE 2 | Mean values \pm 1 S.D. $(n=2)$ of $\mathrm{pH}$, electrical conductivity (EC), organic matter content (\%), total nitrogen $(\mathrm{N})$, Olsen phosphorous $(\mathrm{P})$, and potassium (K), measured under $P$. tamarugo at 50 and $100 \mathrm{~cm}$ depth, at two ranges of groundwater depletion (Salar de Llamara, Pampa del Tamarugal).

\begin{tabular}{|c|c|c|c|c|}
\hline \multirow[b]{3}{*}{ Soil depth $(\mathrm{cm})$} & \multicolumn{4}{|c|}{ Groundwater depth range } \\
\hline & \multicolumn{2}{|c|}{$<1 \mathrm{~m}$} & \multicolumn{2}{|c|}{$6-9 \mathrm{~m}$} \\
\hline & 50 & 100 & 50 & 100 \\
\hline $\mathrm{pH}$ & $8.5 \pm 0.00$ & $8.5 \pm 0.00$ & $8.6 \pm 0.07$ & $8.5 \pm 0.00$ \\
\hline $\mathrm{EC}\left(\mathrm{dS} \mathrm{m}^{-1}\right)$ & $20.0 \pm 3.54$ & $19.9 \pm 2.76$ & $40.6 \pm 1.06$ & $17.2 \pm 3.61$ \\
\hline $\mathrm{OM}(\%)$ & $0.9 \pm 0.64$ & $0.4 \pm 0.00$ & $0.5 \pm 0.51$ & $0.1 \pm 0.04$ \\
\hline $\mathrm{N}\left(\mathrm{mg} \mathrm{Kg}^{-1}\right)$ & $14.5 \pm 10.61$ & $7.0 \pm 4.24$ & $10.5 \pm 2.12$ & $7.5 \pm 2.12$ \\
\hline$P\left(\mathrm{mg} \mathrm{Kg}^{-1}\right)$ & $17.0 \pm 1.41$ & $5.0 \pm 2.83$ & $7.5 \pm 0.71$ & $4.5 \pm 3.54$ \\
\hline $\mathrm{K}\left(\mathrm{mg} \mathrm{Kg}^{-1}\right)$ & $864.5 \pm 2.12$ & $659.0 \pm 1.41$ & $1126 \pm 226.27$ & $526 \pm 189.5$ \\
\hline
\end{tabular}

0.8
0.6
0.0


but trees in the 6-9 $\mathrm{m}$ GWDr had a higher frequency of values 5 of chroma (63\%), that is, lighter green respect to $<1 \mathrm{~m} \mathrm{GWDr}$ which had the same proportion of values 5 and 4 .

The GWDr $\times$ Season interaction was significant for iWUE (Table 4). The GWDr $<1 \mathrm{~m}$ in winter had the lowest iWUE (75.9 $\mu \mathrm{mol} \mathrm{CO}_{2} \mathrm{~mol} \mathrm{H}_{2} \mathrm{O}^{-1}$ ). In all other cases, P. tamarugo had an iWUE greater than $90 \mu \mathrm{mol} \mathrm{CO}_{2} \mathrm{~mol} \mathrm{H}_{2} \mathrm{O}^{-1}$. The GWDr $\times$ Season interaction was significant for $\delta^{13} \mathrm{C}(p=0.0037)$, $\delta^{13} \mathrm{C}$ being lower in the GWDr $<1 \mathrm{~m}$ in winter, while for $\delta^{18} \mathrm{O}$ the interaction was not significant. The greater ${ }^{18} \mathrm{O}$ enrichment was found in summer, independently in the 6-9m GWDr (Table 4).

An increase in the concentration of both ${ }^{13} \mathrm{C}$ and ${ }^{18} \mathrm{O}$ was observed as the groundwater depletion increased during winter. In contrast, the isotopic composition of the leaves $\delta^{13} \mathrm{C}$ measured in summer was similar among GWDrs, but $\delta^{18} \mathrm{O}$ was higher

TABLE 3 | Leaf mass per unit area (LMA), wood density (WD), individual leaf area (LA), and individual leaf mass (LM) measured in winter 2016 in P. tamarugo subjected to $<1(n=5)$ and $6-9 \mathrm{~m}(n=7)$ groundwater depletion ranges (Salar de Llamara, Pampa del Tamarugal).

\begin{tabular}{ccccc}
\hline & LMA & WD & LA & LM \\
GWD range & $\mathrm{g} \mathrm{cm}^{-2}$ & $\mathrm{~g} \mathrm{~cm}^{-3}$ & $\mathrm{~cm}^{2}$ & $\mathrm{~g}$
\end{tabular}

$[<1 \mathrm{~m}] \quad 0.011 \pm 0.001 \mathrm{~B} 0.696 \pm 0.031 \mathrm{~A} 0.114 \pm 0.008 \mathrm{~A} 1.21 \pm 0.168 \mathrm{~A}$ [6-9m] $\quad 0.015 \pm 0.001 \mathrm{~A} 0.720 \pm 0.022 \mathrm{~A} 0.073 \pm 0.004 \mathrm{~B} 1.05 \pm 0.032 \mathrm{~A}$ SIGNIFICANCE (P-VALUE)

$\begin{array}{lllll}\text { GWD range } & 0.0141 & 0.5481 & 0.0034 & 0.3991\end{array}$

Different letters vertically indicate significant differences $(p<0.05)$ according to Fisher's LSD post-hoc analysis.

TABLE 4 | Intrinsic water use efficiency, $\delta^{13} \mathrm{C}$, and $\delta^{18} \mathrm{O}$ of Prosopis tamarugo subjected to $<1 \mathrm{~m}(n=5)$ and $6-9 \mathrm{~m}(n=7)$ of groundwater depletion ranges, in summer and winter of 2016 (Salar de Llamara, Pampa del Tamarugal).

\begin{tabular}{|c|c|c|c|}
\hline & $\begin{array}{c}\text { iWUE } \\
\mu \mathrm{mol} \mathrm{CO} \mathrm{mol} \mathrm{H}_{2} \mathrm{O}^{-1}\end{array}$ & $\begin{array}{c}\delta^{13} \mathrm{C} \\
\%\end{array}$ & $\begin{array}{c}\delta^{18} \circ \\
\% 0\end{array}$ \\
\hline \multicolumn{4}{|l|}{ GWD RANGE } \\
\hline$[<1 \mathrm{~m}]$ & $85.1 \pm 2.37$ & $-26.8 \pm 0.30$ & $31.2 \pm 0.17 \mathrm{~B}$ \\
\hline [6-9m] & $91.4 \pm 1.99$ & $-26.3 \pm 0.17$ & $32.4 \pm 0.35 \mathrm{~A}$ \\
\hline \multicolumn{4}{|l|}{ SEASON } \\
\hline Summer & $93.2 \pm 1.61$ & $-26.1 \pm 0.16$ & $32.3 \pm 0.36 \mathrm{~A}$ \\
\hline Winter & $83.2 \pm 1.95$ & $-27.0 \pm 0.23$ & $31.3 \pm 0.11 \mathrm{~B}$ \\
\hline \multicolumn{4}{|l|}{ INTERACTION } \\
\hline$[<1 \mathrm{~m}] \times$ Summer & $94.3 \pm 2.81 \mathrm{~A}$ & $-26.0 \pm 0.30 \mathrm{~A}$ & $31.8 \pm 0.30 \mathrm{~A}$ \\
\hline$[<1 \mathrm{~m}] \times$ Winter & $75.9 \pm 2.64 \mathrm{~B}$ & $-27.7 \pm 0.38 \mathrm{~B}$ & $30.7 \pm 0.13 \mathrm{~B}$ \\
\hline [6-9 m] x Summer & $92.1 \pm 1.56 \mathrm{~A}$ & $-26.2 \pm 0.13 \mathrm{~A}$ & $32.8 \pm 0.66 \mathrm{~A}$ \\
\hline [6-9 m] x Winter & $90.6 \pm 2.87 \mathrm{~A}$ & $-26.4 \pm 0.26 \mathrm{~A}$ & $32.0 \pm 0.17 \mathrm{~A}$ \\
\hline \multicolumn{4}{|c|}{ SIGNIFICANCE (P-VALUE) } \\
\hline GWD range & 0.0102 & 0.1470 & 0.0090 \\
\hline Season & 0.0001 & 0.0006 & 0.0274 \\
\hline GWD range x Season & 0.0002 & 0.0037 & 0.6359 \\
\hline
\end{tabular}

Different letters indicate significant differences $(p<0.05)$ according to Fisher's LSD post-hoc analysis. Values without letters indicate that the interaction was significant and no comparison among means can be done.

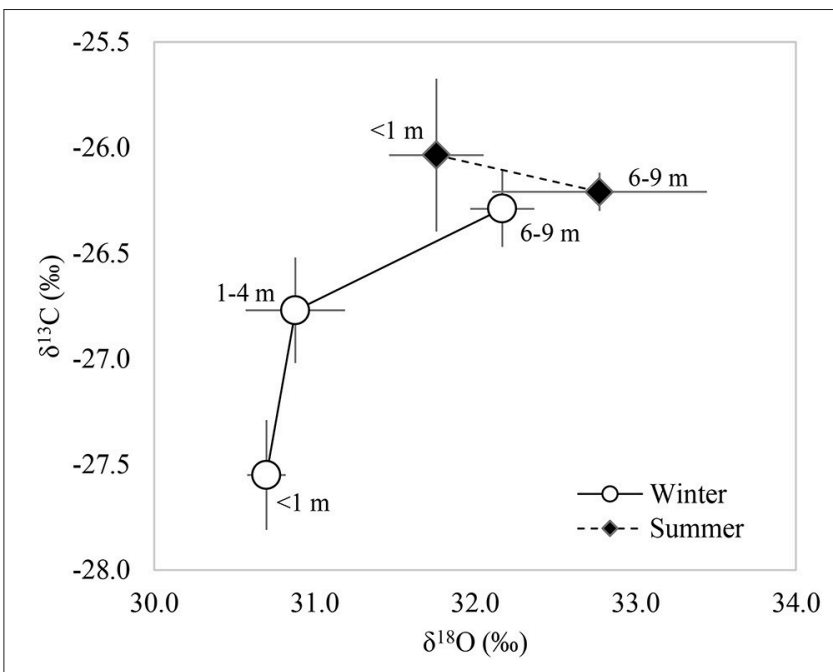

FIGURE 4 | Relationship of the ${ }^{13} \mathrm{C}$ and ${ }^{18} \mathrm{O}$ foliar isotopic compositions measured in $<1(n=5), 1-4 \mathrm{~m}(n=4)$, and 6-9 $\mathrm{m}(n=7)$ groundwater depletion ranges in winter and summer 2016.

in areas with groundwater depletion (Figure 4). An increase in $\delta^{18} \mathrm{O}$ with no variation in $\delta^{13} \mathrm{C}$ (as observed during summer) is interpreted as a decrease in stomatal conductance coordinated with a decrease in net assimilation with increasing GWD; while an increase in both $\delta^{13} \mathrm{C}$ and $\delta^{18} \mathrm{O}$ (as observed in winter) is interpreted as a decrease in stomatal conductance, without significant variation in net assimilation (Scheidegger et al., 2000).

No significant differences were observed between GWDr for IntLength ( $p=0.5503$, Figure 5A). The CSA was significantly higher $(p=0.0314)$ in the $<1 \mathrm{~m}$, decreasing at greater GWDrs (Figure 5B). The trees in the 6-9 m GWDr were significantly shorter $(p=0.0018$, Figure $5 C)$. Significant differences in crown size $(p=0.0195)$ were observed, which increased at lower GWDrs (Figure 5D).

\section{P. tamarugo Water Relationships}

The defoliation and restriction of radial trunk growth maintained a constant $f \mathrm{GCC} \mathrm{CSA}^{-1}$ relation among GWDrs. The GWDr $\times$ Season interaction was significant for $t w i g \Psi_{\mathrm{pd}}(p=$ $0.0009)$ and $t w i g \Psi_{\mathrm{md}}(p=0.00389)$. The largest $t w i g \Psi_{\mathrm{pd}}$ was measured at $<1 \mathrm{~m}$ in summer, while the remaining GWDr $\times$ Season interaction was not significant. The largest twig $\Psi_{\text {md }}$ was observed at the GWDr $<1 \mathrm{~m}$ during winter, and the smallest was in the 6-9 $\mathrm{m}$ in summer. No significant effects of GWDr, season, or their interaction on $g_{s}$ were observed (Table 5). The differences observed between pre-dawn and midday twig $\Psi$ between GWDr were consistently larger in summer than winter, 2 and $1 \mathrm{MPa}$, respectively.

\section{DISCUSSION}

\section{Acclimation of $\boldsymbol{P}$. tamarugo Under Long-Term Groundwater Depletion}

Using Darcy's Law (Equation 5) we can evaluate restrictions and mechanisms of homeostatic compensation on stomatal 

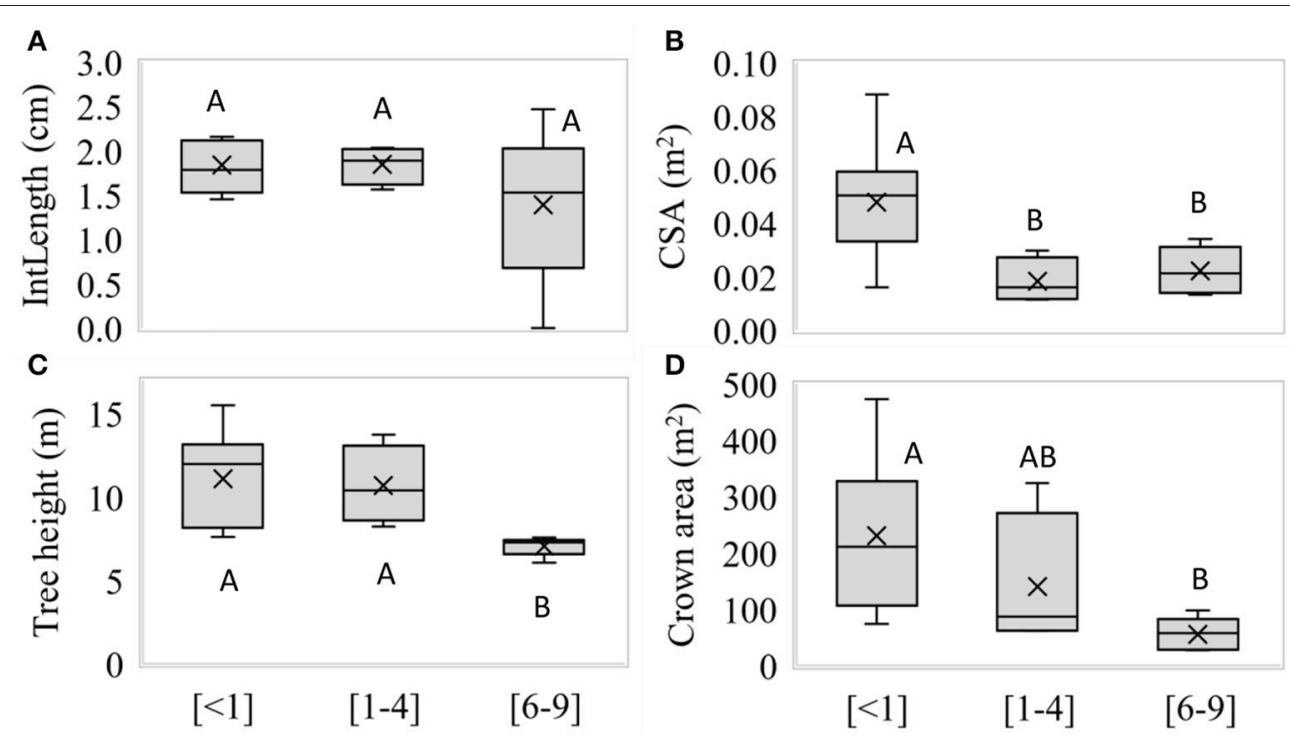

FIGURE 5 | (A) length of internodes, (B) cross-sectional area of stem, (C) tree height, and (D) crown size along $<1(n=5), 1-4 \mathrm{~m}(n=4)$, and $6-9 \mathrm{~m}(n=7)$ groundwater depletion, measured in winter 2016. Different letters indicate significant differences $(p<0.05)$, according to Fisher's LSD post-hoc analysis.

TABLE 5 | Relationship between the leaf cover fraction and trunk transverse section area ( $f$ GCC $\mathrm{CSA}^{-1}$ ), twig water potential at pre-dawn (twig $\Psi \mathrm{pd}$ ) and midday (twig $\Psi \mathrm{md}$ ), and stomatal conductance at midday (porometer gs) of $P$. tamarugo subjected to $<1 \mathrm{~m}(n=5)$ and $6-9 \mathrm{~m}(n=7)$ of groundwater depletion ranges during the summer and winter 2016 (Salar de Llamara, Pampa del Tamarugal).

\begin{tabular}{|c|c|c|c|c|}
\hline & $\begin{array}{c}f G C C \operatorname{CSA}^{-1} \\
-\end{array}$ & $\begin{array}{c}\text { twig } \Psi_{p d} \\
\text { Mpa }\end{array}$ & $\begin{array}{c}\text { twig } \Psi_{\text {md }} \\
\text { Мpa }\end{array}$ & $\begin{array}{c}g_{s} \\
\mathrm{mmol} \mathrm{m} \mathrm{m}^{-2} \mathrm{~s}^{-1}\end{array}$ \\
\hline \multicolumn{5}{|l|}{ GWD RANGE } \\
\hline$<1 \mathrm{~m}$ & $2.1 \pm 0.68 \mathrm{~A}$ & $-1.2 \pm 0.10$ & $-2.7 \pm 0.14$ & $0.108 \pm 0.01 \mathrm{~A}$ \\
\hline $6-9 m$ & $2.6 \pm 0.38 \mathrm{~A}$ & $-1.8 \pm 0.11$ & $-3.1 \pm 0.08$ & $0.116 \pm 0.01 \mathrm{~A}$ \\
\hline \multicolumn{5}{|l|}{ SEASON } \\
\hline Summer & $2.9 \pm 0.66 \mathrm{~A}$ & $-1.33 \pm 0.09$ & $-3.2 \pm 0.10$ & $0.113 \pm 0.01 \mathrm{~A}$ \\
\hline Winter & $1.8 \pm 0.42 \mathrm{~A}$ & $-1.64 \pm 0.09$ & $-2.6 \pm 0.08$ & $0.111 \pm 0.01 \mathrm{~A}$ \\
\hline \multicolumn{5}{|l|}{ INTERACTION } \\
\hline$<1 \mathrm{~m} \times$ Summer & $2.4 \pm 1.13 \mathrm{~A}$ & $-0.9 \pm 0.05 \mathrm{~A}$ & $-2.9 \pm 0.17 \mathrm{~B}$ & $0.120 \pm 0.01 \mathrm{~A}$ \\
\hline$<1 \mathrm{~m} \times$ Winter & $1.8 \pm 0.76 \mathrm{~A}$ & $-1.6 \pm 0.16 \mathrm{~B}$ & $-2.5 \pm 0.14 \mathrm{~A}$ & $0.095 \pm 0.01 \mathrm{~A}$ \\
\hline $6-9 \mathrm{~m} \times$ Summer & $3.3 \pm 0.67 \mathrm{~A}$ & $-1.8 \pm 0.17 \mathrm{~B}$ & $-3.5 \pm 0.10 \mathrm{C}$ & $0.105 \pm 0.01 \mathrm{~A}$ \\
\hline 6-9 m x Winter & $1.9 \pm 0.36 \mathrm{~A}$ & $-1.7 \pm 0.08 \mathrm{~B}$ & $-2.6 \pm 0.06 \mathrm{AB}$ & $0.128 \pm 0.02 \mathrm{~A}$ \\
\hline \multicolumn{5}{|c|}{ SIGNIFICANCE (P-VALUE) } \\
\hline GWDr & 0.5256 & 0.0045 & 0.0551 & 0.5334 \\
\hline Season & 0.2101 & 0.0056 & $<0.0001$ & 0.9149 \\
\hline GWDr x Season & 0.6263 & 0.0009 & 0.0038 & 0.0603 \\
\hline
\end{tabular}

Different letters indicate significant differences ( $p<0.05)$ according to Fisher's LSD posthoc analysis. Values without letters indicate that the interaction was significant and no comparison among means can be done.

conductance $\left(\mathrm{g}_{\mathrm{s}}\right)$ at canopy level (McDowell and Allen, 2015) as follows:

$$
g_{s}=\frac{A_{s} k_{s}\left(\Psi_{s}-\Psi_{l}\right)}{h_{w} \eta A_{l} D_{s}}
$$

where $A_{s}$ is the conductive area $\left(\mathrm{m}^{2}\right), \mathrm{k}_{\mathrm{s}}$ is the specific hydraulic conductivity $\left(\mathrm{m} \mathrm{s}^{-1}\right), \Psi_{\mathrm{s}}-\Psi_{1}$ is the soil-leaf water potential difference $(\Delta \Psi ; \mathrm{MPa}), h_{w}$ is the tree height $(\mathrm{m})$ (an approximation to the hydraulic path length), $\eta$ is the water viscosity ( $\mathrm{Pa} \mathrm{s}), \mathrm{A}_{1}$ is the leaf area $\left(\mathrm{m}^{2}\right)$, and $\mathrm{D}_{\mathrm{s}}$ is the leaf-to-air vapor pressure deficit $(\mathrm{kPa})$.

In summer and winter, $P$. tamarugo had a $\Delta \Psi$ across GWDrs of one and two Mpa, respectively. In this context, the smaller cross-sectional area of trees of the groundwater depletion zones (Figure 5; CSA as a proxy of $A_{s}$ ) would promote a decrease in $g_{s}$ (Equation 5). P. tamarugo compensates for this effect restricting growth in height (Figure 5) and having lower green canopy fraction (i.e., a relatively constant $f \mathrm{GCC} \mathrm{CSA}^{-1}$ ). Keeping wood density constant between GWDrs, it is probable that the maximum specific conductivity of its branches is also maintained constant (Bucci et al., 2004). Even though our study showed no $\mathrm{g}_{\mathrm{s}}$ differences among GWDrs (Table 5), it is important to keep in mind that this variable is highly dynamic in the field, and it is difficult to achieve adequate representativeness in large canopies (Farquhar et al., 2007).

Previous studies have shown that $P$. tamarugo responds to decreases in water table depth by decreasing the radial growth of branches (Decuyper et al., 2016) and through partial crown defoliation (Ortiz, 2010; Chávez et al., 2013; Garrido et al., 2016). Our study showed that drought induced defoliation occurred along with a leaflet size reduction. The leaves of the remnant canopy of the trees growing at 6-9 $\mathrm{m}$ GWDr had higher LMA values. There was a significant leaflet area decreases of $36 \%$, while the leaflet mass decreased by $13 \%$ only (non-significant). A higher LMA usually occurs under a reduced leaf area and is associated with tissue that is more resistant to desiccation under water deficit conditions because of a reduction of the boundary layer that helps to maintain a more favorable leaf temperature (Poorter et al., 2009) and 
a negative association with leaf turgor loss point (Bucci et al., 2004).

The non-increase of cavitation resistance estimated in our study through wood density (Jacobsen et al., 2005, 2007; McCulloh et al., 2012) may be related to the observed winter defoliation increase in the 6-9 m GWDr. A combined effect of water stress and freeze/thaw-induced cavitation (Niu et al., 2017) in an environment with high frost frequency between May and August (minimum of $-4.3^{\circ} \mathrm{C}$ in 2016) would affect water flow to the leaves, promoting senescence. Carevic et al. (2017) observed a decrease in twig hydraulic conductivity of Prosopis burkartii during the winter in the Pampa del Tamarugal.

P. tamarugo has a dual root system (Sudzuki, 1969) through which it performs "hydraulic lifting." This process was described by Richards and Caldwell (1987) and confirmed and renamed "hydraulic redistribution" by Burgess et al. (1998). Aravena and Acevedo (1985) found that the ${ }^{18} \mathrm{O}$ and ${ }^{2} \mathrm{H}$ isotope compositions of the groundwater table and the upper soil water in a tamarugo plantation were similar. Leaves and rootlets tend to be functionally related; both are ephemeral organs, and their main function is the acquisition of resources (Eissenstat et al., 2000), so there would be an association of the foliage and rootlet production (or death) along a resource availability gradient (Hendricks et al., 2006). Thus, the lower presence of roots observed in the field (visual observations only) and lower humidity in the upper soil under P. tamaurugo at 6-9 m GWDr could have a common origin with defoliation.

\section{Analysis of the Intrinsic Water Use Efficiency of $P$. tamarugo Using Stable Isotopes in the Leaf Tissue}

Intrinsic water use efficiency, defined as the relationship between net photosynthesis and stomatal conductance $\left(A_{n} g_{s}^{-1}\right.$; iWUE), integrated over time, and $\delta^{13} \mathrm{C}$ are positively associated (Farquhar et al., 1982). $\delta^{13} \mathrm{C}$ has been used in the study of iWUE of eucalyptus forests subjected to water table depth gradients (Zolfaghar et al., 2017), and in estimating root depth and groundwater use in different forest communities (Rumman et al., 2017).

In summer, leaves showed a discrete $\delta^{18} \mathrm{O}$ increase (Figure 4) but no changes in $\delta^{13} \mathrm{C}$ with increasing GWDr, which would indicate that GWDr lowering has no effect on iWUE due to a coordinated decrease in both gs and An over time, according to the dual isotopic model (Scheidegger et al., 2000). The estimated iWUE for this period was 94.3 and $92.1 \mu \mathrm{mol} \mathrm{CO} \mathrm{Col} \mathrm{H}_{2} \mathrm{O}^{-1}$ in $<1$ and 6-9 $\mathrm{m}$ GWDrs, respectively. During winter, however, (i.e., after the end of the P. tamarugo more active growth cycle), the estimated iWUE was 75.9 and $90.6 \mu \mathrm{mol} \mathrm{CO} \mathrm{Col} \mathrm{H}_{2} \mathrm{O}^{-1}$ for $<1$ and $6-9 \mathrm{~m}$ GWDrs, respectively. The greater iWUE at higher groundwater depletion can be the result of a decrease in $g_{s}$ without substantive changes in $A_{n}$ over time (Figure 4), given the positive association between $\delta^{13} \mathrm{C}$ and $\delta^{18} \mathrm{O}$. This behavior could be explained by the slight effect of groundwater depletion on $\mathrm{g}_{\mathrm{s}}$ in the remaining $P$. tamarugo canopy, which is not detected through porometry due to its high variability.
Following a defoliation event, some species experience a transient increase in the photosynthetic rate as a compensation mechanism against photosynthetic tissue reduction (Pinkard et al., 2007; Eyles et al., 2009). Chávez et al. (2013) observed an increase in carotenoid and chlorophyll $\mathrm{a}+\mathrm{b}$ concentrations in P. tamarugo leaves subjected to prolonged periods of groundwater depletion, that could be due to a concentration phenomenon given LMA increase observed in our study, which could be associated to the maintenance of the net photosynthesis rate at deeper groundwater levels.

\section{Ecological Implications of Groundwater Depletion in Pampa del Tamarugal Ecosystem}

Among the different ecological aspects affected by the groundwater depletion in the Pampa del Tamarugal, it has been shown that hydraulic redistribution, i.e., the movement of water from the water table to the upper soil through the root system, has implications at the plant, community, and ecosystem levels (Prieto et al., 2012). Regarding P. tamarugo, it could have significant importance in avoidance of root cavitation during the day, because of an increase of water availability during night (Domec et al., 2004), affecting the processes regulated by soil moisture, such as nutrient absorption, nitrogen mineralization, soil respiration, enzymatic activity, and soil productivity determination (Burgess et al., 1998; Cardon et al., 2013). In addition, the effect of hydraulic redistribution as a buffer for the effects of severe soil drying for rhizosphere fungi, has been observed in California Oak savanna during the Mediterranean summer dry period (Querejeta et al., 2007). Specifically, in desert conditions, the reduction of water availability and high salinity affects negatively native Rhizobium bacteria, decreasing their population, their inoculation capacity, and symbiotic $\mathrm{N}_{2}$ fixation in woody species of the genus Prosopis (Zahran, 1999). In our study, the observed higher volumetric water content, $\mathrm{OM}, \mathrm{N}$, and P-Olsen, and a lower EC in a condition without groundwater depletion is related to the process affected by hydraulic redistribution mentioned above. In the same way, the observed higher frequency of lighter green leaves under groundwater depletion may be related with lower chlorophyll contents by $\mathrm{N}$ deficit. Therefore, in addition to water stress induced by groundwater depletion, availability and symbiotic fixation of $\mathrm{N}$ could be affected through the reduction of hydraulic redistribution and increase of the concentration of salts in the upper soil layers, limiting ecosystem sustainability.

To date, important progress has been made in conserving P. tamarugo. With the species declared as endangered by the Chilean Ministry of the Environment, the relict forest of the Salar de Llamara became part of the Pampa del Tamarugal National Reserve and water rights ceased to be issued in the area. While these efforts move in the right direction, ensuring the water provision to $P$. tamarugo is a key issue, and it is therefore necessary to reduce the water extraction rate, through water rights expropriation and/or the use of alternative water sources for urban and mining uses, such as desalted seawater. It is also advisable to explore ways that allow the forest to increase its 
tolerance to water deficit and promote its capacity for recovery, as well as bringing the community and stakeholders closer to the reality of this ecosystem, and the benefits associated with its conservation.

\section{CONCLUSIONS}

The morpho-physiological and structural traits adjustment experienced by $P$. tamarugo after 10 years of exposure to groundwater depletion, have allowed it to acclimate and survive. The strategy of $P$. tamarugo consists mainly in an active control of its canopy, maintaining functional but decreased canopy, with small leaves having high stomatal conductance and photosynthesis (estimated from leaf isotopic composition), but exposed to low water potentials. The groundwater depletion negatively affects the root hydraulic redistribution, reducing water availability in the soil under $P$. tamarugo canopy, with known consequences in both, edaphic microbiota, such as atmospheric nitrogen fixation, adding stressors associated to plant nutrition and soil salinity. Although conservation initiatives of the species are moving in the right direction, forest deterioration is expected continue as groundwater depth increases.

\section{REFERENCES}

Addington, R. N., Donovan, L. A., Mitchell, R. J., Vose, J. M., Pecot, S. D., Jack, S. B., et al. (2006). Adjustments in hydraulic architecture of Pinus palustris maintain similar stomatal conductance in xeric and mesic habitats. Plant Cell Environ. 29, 535-545. doi: 10.1111/j.1365-3040.2005.01430.x

Allen, C. D., Macalady, A., Chenchouni, H., Bachelet, D., McDowell, N., Vennetier, M., et al. (2010). A global overview of drought and heat-induced tree mortality reveals emerging climate change risks for forests. For. Ecol. Manage. 259, 660-684. doi: 10.1016/j.foreco.2009.09.001

Aravena, R., and Acevedo, E. (1985). "The use of environmental isotopes oxigen18 and deuterium in the study of wáter relations of Prosopis tamarugo Phil," in The Current State of Knowledge of Prosopis tamarugo, ed M. Habit (NewYork, NY: Food and Agriculture Organization of The United Nations), 251-256.

Bidak, L., Kamal, S., Waseem, M., Halmy, A., and Heneidy, S. (2015). Goods and services provided by native plants in desert ecosystems: examples from the northwestern coastal desert of Egypt. Glob. Ecol. Conserv. 3, 433-447. doi: 10.1016/j.gecco.2015.02.001

Bozdogan, H. (1987). Model selection and akaike'is information criterion (AIC): thegeneral theory and its analytical extensions. Psychrometrica 52, 345-370. doi: 10.1007/BF02294361

Bucci, S., Goldstein, G., Mainzer, F., Scholz, F., and Franco, A. (2004). Functional convergence in hydraulic architecture and water relations of tropical savanna trees: from leaf to whole plant. Tree Physiol. 24, 891-899. doi: 10.1093/treephys/24.8.891

Burgess, S. S. O., Adams, M. A., Turner, N. C., and Ong, C. K. (1998). The redistribution of soil water by tree root systems. Oecologia 115, 306-311. doi: $10.1007 /$ s004420050521

Calderón, G., Garrido, M., and Acevedo, E. (2015). Prosopis tamarugo Phil.: a Native tree from the Atacama Desert. Ground water table depth thresholds for conservation. Rev. Chil. Hist. Nat. 88:18. doi: 10.1186/s40693-015-0048-0

Canham, C. A., Froend, R. H., and Stock, W. D. (2009). Water stress vulnerability of four Banksia species in contrasting ecohydrological habits on the Gnangara Mound, Western Australia. Plant Cell Environ. 32, 64-72. doi: 10.1111/j.1365-3040.2008.01904.x

Cardon, Z. G., Stark, J. M., Herron, P. M., and Rasmussen, J. A. (2013). Sagebrush carrying out hydraulic lift enhances surface soil nitrogen cycling and nitrogen

\section{AUTHOR CONTRIBUTION}

MG designed the experiment, collected data, and drafted this manuscript. HS designed the experiment, collected data, and edited the manuscript. NF edited the manuscript. JA provided logistic support and edited the manuscript. EA followed and discussed upon data collection, provided support through the Soil-Water-Plant Relations Laboratory and edited the manuscript.

\section{ACKNOWLEDGMENTS}

This study was financed by FONDECYT Project No. 1150799 and the Advanced Human Capital Project CONICYTPCHA/NationalDoctorate/2015-21150807. Special thanks to the administrator of the Canchones Experimental Station of Universidad Arturo Prat, Mr. Marcelo Rojas. We also thank the students of the Soil-Water-Plant Relations Laboratory, Adolfo Pardo and José Ayamante for their collaboration during data collection, and the Agronomists Pablo Cortés, and Mirko Talamilla (Universidad de Chile) for their significant collaboration during the field seasons in the Pampa del Tamarugal.

uptake into inflorescences. Proc. Natl. Acad. Sci. U.S.A. 110, 18988-18993. doi: $10.1073 /$ pnas. 1311314110

Carevic, F., Delatorre, J., and Carrasco, A. (2017). Plant water variable and reproductive traits are influenced by seasonal climatic variables in Prosopis burkartii (Fabaceae) at Northern Chile. Flora 233, 7-11. doi: 10.1016/j.flora.2017.04.012

Chávez, R., Clevers, J., Decuyper, M., and Herold, M. (2016). 50 years of water extraction in the Pampa del Tamarugal basin: can Prosopis tamarugo trees survive in the hyper-arid Atacama Desert (Northern Chile). J. Arid Environ. 124, 292-303. doi: 10.1016/j.jaridenv.2015. 09.007

Chávez, R., Jan, G., Clevers, W., Herold, M., Acevedo, E., and Ortiz, M. (2013). Assessing water stress of desert tamarugo trees using in situ data and very high spatial resolution remote sensing. Remote. Sens. 5, 5064-5088. doi: $10.3390 /$ rs5105064

Colangelo, M., Camarero, J., Battiplagia, G., Borghetti, M., De Micco, V., Gentilesca, T., et al. (2017). A multi-proxy assessment of dieback causes in a Mediteranean oak species. Tree Physiol. 37, 617-631. doi: 10.1093/treephys/tpx002

Cruiziat, P., Cochard, H., and Améglio, T. (2002). Hydraulic architecture of trees: main concepts and results. Ann. For. Sci. 59, 723-752. doi: 10.1051/forest:2002060

Decuyper, M., Chávez, R., Copini, P., and Sass-Klaassen, U. (2016). A multi-scale approach to access the effect of groundwater extraction on Prosopis tamarugo in the Atacama Desert. J. Arid Environ. 131, 25-34. doi: 10.1016/j.jaridenv.2016.03.014

De Micco, V., and Aronne, G. (2012). "Morpho-anatomical traits for plant adaptation to drought," in Plant Responses to Drought Stress, ed R. Aroca (Berlin: Springer-Verlag), 37e61.

Di Rienzo, J. A., Casanoves, F., Balzarini, M. G., Gonzalez, L., Tablada, M., and Robledo, Y. C. (2011). InfoStat Versión 2011. Grupo InfoStat, FCA Universidad Nacional de Córdoba, Argentina. Available online at: http://www.infostat. com.ar.

Domec, J. C., Warren, J. M., and Meinzer, F. C. (2004). Native root xylem embolism andstomatal closure in stands of Douglas-fir and ponderosa pine: mitigation byhydraulic redistribution. Oecologia 141, 7-16. doi: 10.1007/s00442-004-1621-4 
Eamus, D., Cleverly, J., Boulain, N., Grant, N., Faux, R., and Villalobos-Vega, R. (2013). Carbon and water fluxes in an arid-zone Acacia savanna woodland: an analyses of seasonal patterns and responses to rainfall events. Agric. For. Meteorol. 182, 225-238. doi: 10.1016/j.agrformet.2013.04.020

Eamus, D., O'Grady, A., and Hutley, L. (2000). Dry season conditions determine wet season water use in the wet-tropical savannas of northern Australia. Tree Physiol. 20, 1219-1226. doi: 10.1093/treephys/20.18.1219

Eissenstat, D. M., Wells, C. E., Yanai, R. D., and Whitbeck, J. L. (2000). Building roots in a changing environment: implications for root longevity. New Phytol. 147, 33-42. doi: 10.1046/j.1469-8137.2000.00686.x

Eyles, A., Pinkard, E. A., and Mohammed, C. L. (2009). Shifts in biomass and resource allocation patterns following defoliation in Eucalyptus globulus growing with varying water and nutrient supplies. Tree Physiol. 29, 753-764. doi: 10.1093/treephys/tpp014

Farquhar, G. D., Cernusak, A., and Barnes, B. (2007). Heavy water fractionation during transpiration. Plant Physiol. 143, 11-18. doi: 10.1104/pp.106.093278

Farquhar, G. D., O'Leary, M. H., and Berry, J. A. (1982). On the relationship between carbon isotope discrimination and the intercellular carbon dioxide concentration in leaves. Funct. Plant Biol. 9, 121-137. doi: 10.1071/PP9820121

Fortunel, C., Ruelle, J., Beauchêne, J., Fine, P. V. A., and Baraloto, C. (2014). Wood specific gravity and anatomy of branches and roots in 113 Amazonian rainforest tree species across environmental gradients. New Phytol. 202, 79-94. doi: $10.1111 / \mathrm{nph} .12632$

Garrido, M., Silva, P., and Acevedo, E. (2016). Water relations and foliar isotopic composition of Prosopis tamarugo Phil., an endemic tree of the Atacama Desert growing at three levels of water table depth. Front. Plant Sci. 7:375. doi: $10.3389 /$ fpls.2016.00375

Gehring, E., Boris, G., Krebs, P., Mazzoleni, S., Zappa, M., and Conedera, M. (2016). The influence of site characteristics on the leaf-to-sapwood area relationship in chestnut trees (Castanea sativa Mill.). Trees 30, 2217-2226. doi: 10.1007/s00468-016-1447-9

Gotsch, S. G., Geiger, E. L., Franco, A. C., Goldstein, G., Meinzer, F. C., and Hoffmann, W. A. (2010). Allocation to leaf area and sapwood area affects water relations of co-occurring savanna and forest trees. Oecologia 163, 291-301. doi: 10.1007/s00442-009-1543-2

Hacke, U. G., Sperry, J. S., Pockman, W. T., Davis, S. D., and McCulloh, K. A. (2001). Trends in wood density and structure are linked to prevention of xylem implosion by negative pressure. Oecologia 126, 457-461. doi: $10.1007 / \mathrm{s} 004420100628$

Hendricks, J. J., Hendrick, R. L., Wilson, C. A., Mitchell, R. J., Pecot, S. D., and Guo, D. L. (2006). Assessing the patterns and controls of fine root dynamics: an empirical test and methodological review. J. Ecol. 94, 40-57. doi: 10.1111/j.1365-2745.2005.01067.x

Jacobsen, A. L., Ewers, F. W., Pratt, R. B., Paddock, W. A., and Davis, S. D. (2005). Do xylem fibers affect vessel cavitation resistance? Plant Physiol. 139, 546-556. doi: 10.1104/pp.104.058404

Jacobsen, A. L., Pratt, R. B., Ewers, F. W., and Davis, S. D. (2007). Cavitation resistance among 26 chaparral species of southern California. Ecol. Monogr. 77, 99-115. doi: 10.1890/05-1879

Kelley, G., O'Grady, A., Hutley, L., and Eamus, D. (2007). A comparison of tree water use in two contiguous vegetation communities of the seasonally dry tropics of northern Australia: the importance of site water budget to tree hydraulics. Aust. J. Bot. 55, 700-708. doi: 10.1071/BT07021.

Lehner, G., Delatorre, J., Lütz, C., and Cardemil, L. (2001). Field studies on the photosynthesis of two desert Chilean plants: Prosopis chilensis and Prosopis tamarugo. J. Photochem. Photobiol. B Biol. 64, 36-44. doi: 10.1016/S1011-1344(01)00187-7

Maherali, H., Pockman, W. T., and Jackson, R. B. (2004). Adaptive variation in the vulnerability of woody plants to xylem cavitation. Ecology 85, 2184-2199. doi: 10.1890/02-0538

Mainzer, F., Johnson, D., Lachenbruch, B., McCulloh, K., and Woodruff, D. (2009). Xylem hydraulic safety margins in woody plant: coordination of stomatal control of xylem tensión with hydraulic capacitance. Funct. Ecol. 23, 922-930. doi: 10.1111/j.1365-2435.2009.01577.x

McCulloh, K. A., Johnson, D. M., Meinzer, F. C., Voelker, S. L., Lachenbruch, B., and Domec, J. C. (2012). Hydraulic architecture of two species differing in wood density: opposing strategies in co-occurring tropical pioneer trees. Plant Cell Environ. 35, 116-125. doi: 10.1111/j.1365-3040.2011.02421.x
McDowell, N., and Allen, C. (2015). Darcy's law predicts widespread forest mortality under climate warming. Nat. Clim. Change 5, 669-672. doi: 10.1038/ nclimate 2641

Niu, C., Meinzer, F., and Hao, G. (2017). Divergence in strategies for coping with winter embolism among co-occurring temperate tree species: the role of positive xylem pressure, wood type and tree stature. Funct. Ecol. 31, 1550-1560. doi: $10.1111 / 1365-2435.12868$

Ortiz, M. (2010). Nivel Freático en la Pampa del Tamarugal y crecimiento de Prosopis tamarugo Phil. Thesis doctoral programa de doctorado en ciencias silvoagropecuarias y veterinarias, Universidad de Chile.

Pérez, N., Díaz, S., Garnies, E., Lavorel, S., Poorter, H., Jaureguiberry, P., et al. (2013). New handbook for standardised measurement of plant functional traits worldwide. Aust. J. Bot. 61, 167-234. doi: 10.1071/BT12225

Pinheiro, J. C., and Bates, D. M. (2000). Mixed Effects Models in S and S-Plus. New York, NY: Spring-Verlag

Pinkard, E. A., Battaglia, M., and Mohammed, C. L. (2007). Defoliation and nitrogen effects on photosynthesis and growth of Eucalyptus globulus. Tree Physiol. 27, 1053-1063. doi: 10.1093/treephys/27.7.1053

Pliscoff, P., and Leubert, F. (2006). Sinopsis Bioclimática y Vegetacional de Chile. Santiago: Editorial Universitaria.

Poorter, H., Niinemets, Ü., Poorter, L., Wright, I., and Villar, R. (2009). Causes and consequences of variation in leaf mass per area (LMA): a meta-analysis. New Phytol. 182, 565-588. doi: 10.1111/j.1469-8137.2009.02830.x

Prieto, I., Armas, C., Pugnaire, F. I. (2012). Water release through plant roots: new insights into its consequences at the plant and ecosystem level. New Phytol. 193, 830-841. doi: 10.1111/j.1469-8137.2011.04039.x

Querejeta, J. I., Egerton-Warburton, L. M., and Allen, M. F. (2007). Hydraulic lift may buffer rhizosphere hyphae against the negative effects of severe soil drying in a Califormia Oak savanna. Soil Biol. Biochem. 39, 409-417. doi: 10.1016/j.soilbio.2006.08.008

R Core Team (2015). R: Language and Environment for Statistical Computing. Vienna: R Foundation for Statistical Computing. Available online at: http://Rproject.org/.

Richards, J. H., and Caldwell, M. M. (1987). Hydraulic lift: substantial nocturnal water transport between soil layers by Artemisia tridentata roots. Oecologia 73, 486-489 doi: 10.1007/BF00379405

Roden, J., and Farquhar, G. D. (2012). A controlled test of the dual-isotope approach for the interpretation of stable carbon and oxygen isotope ratio variation in tree rings. Tree Physiol. 32, 490-503. doi: 10.1093/treephys/tps019

Roden, J., and Siegwolf, R. (2012). Is the dual-isotope conceptual model fully operational? Tree Physiol. 32, 1179-1182. doi: 10.1093/treephys/tps099

Rojas, R., Batelaan, O., Feyen, L., and Dessargues, A. (2013). Assessment of conceptual model uncertainty for the regional aquifer Pampa del Tamarugal- North Chile. Hydrol. Earth Syst. Sci. 14, 171-192. doi: 10.5194/hess-14-171-2010

Rood, S., Patino, S., Coomds, K., and Tyree, M. (2000). Branch sacrifice: cavitationassociated drought adaptation of riparian cottonwoods. Trees Struct. Funct. 14, 248-257. doi: 10.1007/s004680050010

Rumman, R., Cleverly, J., Nolan, R., Tarin, T., and Eamus, D. (2017). Speculations on the application of foliar ${ }^{13} \mathrm{C}$ discrimination to reveal groundwater dependency of vegetation, provide estimates of root depth and rates of groundwater use. Hydrol. Earth Syst. Sci. 1-25. doi: 10.5194/hess-2017-540

Scheidegger, Y., Saurer, M., Bahn, M., and Siegwolf, R. (2000). Linking stable oxygen and carbon isotopes with stomatal conductance and photosynthetic capacity: a conceptual model. Oecologia 125, 350-357. doi: $10.1007 / \mathrm{s} 004420000466$

Schindelin, J., Rueden, C. T., and Hiner, M. C., et al. (2015). “The ImageJ ecosystem: an open platform for biomedical image analysis”. Mol. Reprod. Dev. 82, 518-529. doi: 10.1002/mrd.22489

Scholander, P. F., Bradstreet, E. D., Hemmingsen, E. A., and Hammel, H. T. (1965). Sap pressure in vascular plants: negative hydrostatic pressure can bemeasuredinplants. Science 148, 339-346. doi: 10.1126/science.148.3668.339

Shadwell, E., and February, E. (2017). Effects of groundwater abstraction on two keystone tree species in an arid savanna national park. PeerJ 5:e2923. doi: 10. $7717 /$ peerj. 2923

Sperry, J. S., Mainzer, F. and, McCulloh, K., (2008). Safety and efficiency conflicts in hydraulic architecture: scaling from tissue to trees. Plant Cell Environ. 31, 632-645. doi: 10.1111/j.1365-3040.2007.01765.x 
Sperry, J. S., and Saliendra, N. Z. (1994). Intra-and inter-plant variation in xylem cavitation in Betula occidentalis. Plant Cell Environ. 17, 1233-1241. doi: 10.1111/j.1365-3040.1994.tb02021.x

Squella, C. (2013). Respuestas de Tamarugo (Prosopis tamarugo Phil.) a un estado hídrico decreciente en el Salar de Llamara. Thesis Universidad de Chile for the degree of Magister en Ciencias agropecuarias in the year 2013.

Sudzuki, F. (1969). Absorción foliar de humedad atmosferica en tamarugo, Prosopis tamarugo Phil. Univ. Chil. Facult. Agron. Bol. Tecnico 30, 1-23.

Tognetti, R., Lombardi, F., Lasserre, B., Cherubini, P., and Marchetti, M. (2014). Tree-ring stable isotopes reveal twentieth-century increases in wateruse efficiency of Fagus sylvatica and Nothofagus spp. in Italian and Chilean Mountains. PLoS ONE 9:e113136. doi: 10.1371/journal.pone.0113136

Tyree, M. T., Davis, S. D., and Cochard, H. (1994). Biophysical perspectives of xylem evolution: is there a tradeoff of hydraulic efficiency for vulnerability dysfunction? IAWA J. 15, 335-360.

Voltas, J., Camarero, J. J., Carulla, D., Aguilera, M., Ortiz, A., and Ferrio, J. P. (2013). A retrospective, dual-isotope approach reveals individual predispositions to winter-drought induced tree dieback in the southernmost distribution limit of Scots pine. Plant Cell Environ. 36, 1435-1448. doi: $10.1111 /$ pce. 12072
Williams, A., Allen, C., Macalady, A., Griffin, D., Woodhouse, C., Meko, D., et al. (2013). Temperature as a potent driver of regional forest drought stress and tree mortality. Nat. Clim. Change 3, 292-297. doi: 10.1038/nclimate1693

Zahran, H. H. (1999). Rhizobium-Legume symbiosis and nitrogen fixation under severe conditions and in an arid climate. Microbiol. Mol. Biol. Rev. 63, 968-989.

Zolfaghar, S., Villalobos-Vega, R., Zeppel, M., Clevery, J., Rumman, R., Hingee, M., et al. (2017). Transpiration of Eucalyptus woodlands across a natural gradient of depth-to-groundwater. Tree Physiol. 37, 961-975. doi: 10.1093/treephys/tpx024

Conflict of Interest Statement: The authors declare that the research was conducted in the absence of any commercial or financial relationships that could be construed as a potential conflict of interest.

Copyright $\odot 2018$ Garrido, Silva, Franck, Arenas and Acevedo. This is an open-access article distributed under the terms of the Creative Commons Attribution License (CC $B Y)$. The use, distribution or reproduction in other forums is permitted, provided the original author(s) and the copyright owner are credited and that the original publication in this journal is cited, in accordance with accepted academic practice. No use, distribution or reproduction is permitted which does not comply with these terms. 